\title{
USAHA PEMBINAAN PENGEMBANGAN PROFESI GURU DAN IMPLIKASINYA TERHADAP MUTU PENDIDIKAN DI MTS TARBIYAH ISLAMIAH KABUPATEN TANAH DATAR
}

\author{
Zlviana \\ Guru MTI Pariangan, Kabupaten Tanah Datar
}

\begin{abstract}
The purpose of this research was to know the implementation of teachers' professional development in Islamic Secondary School Tarbiyah Islamiah Tanah Datar and the impact of the implementation of the teachers' professional development to the quality of education in Islamic Secondary School Tarbiyah Islamiah Tanah Datar. This research was qualitative case study. The result obtained indicate that particularly in Islamic Secondary School Tarbiyah Islamiah Pariangan, Islamic Secondary School Tarbiyah Islamiah Tanjung Barulak and Islamic Secondary School Tarbiyah Islamiah Jaho were not good, the coaching responsibilities of teachers professional development is still left to the headmaster and the participation of regional government was less.
\end{abstract}

Keywords: Teachers' Professional Development, Islamic Secondary School, Tarbiyah Islamiah, Quality of Education, Tanah Datar.

\section{PENDAHULUAN}

Dalam rangka meningkatkan mutu pendidikan di Indonesia diperlukan upaya yang serius untuk meningkatkan kualitas guru. Di Madrasah, Kepala Madrasah yang berperan dalam meningkatkan kualitas guru. Peningkatan mutu pendidikan dapat dimulai dengan meningkatkan mutu guru dalam mengajar dan berprilaku profesional. Selain melalui program sertifikasi, berbagai penataran dan pelatihan guru juga merupakan bentuk dari upaya pembinaan profesi guru.
Kunandar (2008) mengemukakan profesi guru adalah keahlian dan kewenangan khusus dalam bidang pendidikan, pengajaran, dan pelatihan yang ditekuni untuk menjadi mata pencaharian dalam memenuhi kebutuhan hidup yang bersangkutan. Guru sebagai profesi berarti guru sebagai pekerjaan yang mensyaratkan kompetensi (keahlian dan kewenangan) dalam pendidikan dan pembelajaran agar dapat melaksanakan pekerjaan tersebut secara efektif dan efisien serta berhasil guna.

Guru profesional adalah orang yang memiliki keahlian dalam bidang keguruan 
sehingga ia melakukan tugas dan fungsinya sebagai guru dengan kemampuan maksimal serta memiliki pengalaman yang kaya di bidangnya. Guru yang professional akan tercermin dalam pelaksanaan pengabdian tugas-tugas yang ditandai dengan keahlian baik dalam materi maupun dalam metode. Selain itu, juga ditunjukkan melalui tanggung jawabnya dalam melaksanakan seluruh pengabdiannya (Kunandar, 2008).

Dengan adanya guru yang profesional dan berkualitas maka akan mampu mencetak anak bangsa yang berkualitas pula. Kunci yang harus dimiliki oleh setiap pengajar adalah kompetensi. Kompetensi adalah seperangkat ilmu serta keterampilan mengajar guru di dalam menjalankan tugas profesionalnya sebagai seorang guru sehingga tujuan dari pendidikan bisa dicapai dengan baik. Undang-Undang Nomor 14 Tahun 2005 tentang Guru dan Dosen menegaskan bahwa guru dan dosen wajib memiliki kualifikasi akademik, kompetensi, sertifikat guru, sehat jasmani dan rohani, dan memenuhi kualifikasi lain yang dipersyaratkan satuan guru tempat bertugas, serta memiliki kemampuan untuk mewujudkan tujuan guru nasional.

Pada sisi lain, UU Nomor 14 tahun 2005 tentang guru dan dosen mengamanatkan bahwa terdapat dua alur pembinaan dan pengembangan profesi guru, yaitu pembinaan dan pengembangan profesi, dan pembinaan dan pengembangan karir. Pembinaan dan Pengembangan Profesi Guru (PPPG) meliputi pembinaan kompetensi pedagogik, kepribadian, sosial, dan profesional. Undang-undang guru dan dosen secara gamblang dan jelas mengatur secara detail aspek-aspek yang selama ini belum diatur secara rinci. Namun demikian pada kenyataan yang ada di lapangan, masih banyak dijumpai guru yang mengajar di luar bidang keahliannya (mismatch) sebagai contoh guru Agama Islam mengajarkan mata pelajaran Matematika, IPS, Bahasa Inggris dan Bahasa Indonesia dikarenakan tidak cukupnya jam pelajaran yang diampu sehingga guru tersebut harus mengajar mata pelajaran lain untuk memenuhi 24 jam tatap muka. Hal ini juga disebabkan banyaknya guru-guru PNS yang dimutasikan ke Madarasah Tsanawiyah Swasta yang memiliki latar belakang guru agama Islam.

Dalam beberapa kasus lain ada juga sebagian guru yang mengajar tidak membuat RPP, dan tidak bisa menggunakan media pembelajaran. Guru seolah bersikap asalasalan dalam menyiapkan perangkat mengajar. Fenomena lain yang dapat ditemui adalah sewaktu mengajar, guru sering berada di kantor dan guru cendrung ingin cepat pulang setelah jam mengajar selesai seolah-olah kurang betah berada di 
sekolah. Padahal, seharusnya guru berinisiatif melaksanakan berbagai kegiatan di sekolah di luar jam mengajarnya untuk meningkatkan kompetensi di bidang akademik, maupun non akademik, sehingga bisa menjadi guru yang profesional, kreatif dan inovatif sesuai dengan tuntutan regulasi yang ada.

Dari fenomena di atas untuk mecapai mutu pendidikan yang baik diperlukan pembinaan terhadap guru dalam menjalankan tugas guru yang sesuai dengan tuntutan regulasi. Guru yang hebat adalah guru yang kompeten secara metodologi pembelajaran dan keilmuan. Tautan keduanya tercermin dalam kinerjanya selama tranformasi pembelajaran. Dalam konteks transformasi inilah guru harus memiliki kompetensi.

\section{PEMBINAAN PENGEMBANGAN PROFESI GURU}

Pembinaan dan pengembangan profesi guru merupakan kewajiban sekolah dalam rangka menempatkan guru sebagai mitra profesi yang bergerak pada pelayanan jasa. Karenanya, pimpinan sekolah dalam hal ini memegang peranan penting untuk melaksanakan secara berkesinambungan (Mujtahid, 2011). Untuk menjaga mutu pembelajaran, lembaga pendidikan harus berupaya memberikan pembinaan dan pengembangan profesi guru. Upaya ini dilakukan untuk memberikan dorongan para guru agar tetap mempunyai semangat dan motivasi yang sama dalam mengemban tugasnya sebagai tenaga pendidik.

Pengertian pembinaan dalam konteks proses perbaikan mengacu kepada suatu aktivitas konstruktif yang bertujuan membentuk, menciptakan kualitas sesuatu agar lebih baik. Dalam pengertian ini diartikan sebagai proses restrukturisasi kualitas terhadap suatu hal yang dinilai kurang memadai menjadi bantuk kualitas yang lebih baik dan lebih memadai. Sedangkan pembinaan sebagai upaya pengembangan (development, improvement) menunjukkan aktivitas untuk meningkatkan kualitas sesuai dengan yang diharapkan.

Pembinaan juga berkaitan dengan fungsifungsi dan usaha-usaha untuk meningkatkan daya guna manusia dalam proses kerja sama untuk mencapai tujuan bersama yang dilakukan melalui usaha menciptkan suasana kerja yang dapat mendorong untuk dapat mengembangkan potensi secara optimal. Adapun tujuan pembinaan sendiri diciptakan untuk mengembangkan kemampuan agar dapat melaksanakan tugas dan fungsi kerja lebih baik, lebih efektif, lebih terampil dan lebih sistematik dalam melakukan suatu pekerjaan. Jadi, tugas pokok pembinaan adalah usaha-usaha yang harus dilakukan untuk mendapatkan dan 
memelihara serta membina pegawai ke arah suatu kapabilitas dalam suasana kerja yang menyenangkan dan memanfaatkan pegawai secara efektif, efisien, dan dapat dipertanggungjawabkan, yang dalam hal ini adalah aktivitas para kepala sekolah dalam upaya meningkatkan kemampuan profesional kinerja para guru.

Good Dictionary of Education mendefinisikan profesi sebagai "suatu pekerjaan yang meminta persiapan spesialisasi yang relatif khusus" (Sutisna, 1983). Menurut Tim Redaksi KBBI (2001), profesi diartikan sebagai "bidang pekerjaan yang dilandasi pendidikan keahlian tertentu. Jika selama ini profesi hanya dimaknai sekedar "pekerjaan”, sementara substansi dibalik makna itu tidak terpaut dengan persyaratan, maka profesi tidak bisa dipakai di dalam semua pekerjaan.

\section{PEMBINAAN PENGEMBANGAN KARIER GURU}

Membicarakan perencanaan karier, tidak terlepas dari konsep-konsep dasar mengenai karier, jenjang karier, tujuan karier, perencanaan karier, dan pengembangan karier (Rivai, 2009). Pertama, karier merupakan seluruh posisi kerja yang dijabat selama siklus kehidupan pekerjaan seseorang. Kedua, jenjang karier merupakan model posisi pekerjaan berurutan yang membentuk karier seseorang. Ketiga, tujuan karier merupakan posisi mendatang yang diupayakan pencapaiannya oleh seseorang sebagai bagian kariernya. Keempat, perencanaan karier merupakan proses dimana kita menyeleksi tujuan karier dan jenjang karier menuju tujuan-tujuan tersebut. Kelima, pengembangan karier terdiri dari peningkatan pribadi yang dilakukan oleh seseorang dalam mencapai rencana karier pribadi.

Tujuan umum dari pembinaan dan pengembangan karier pendidik pada satuan pendidikan/sekolah adalah meningkatnya kemampuan dan karier pendidik sehingga dapat melaksanakan tugas pokok dan fungsinya sebagai pendidik pada satuan pendidikan/ sekolah yang profesional. Tujuan tersebut mengimplikasikan pentingnya pembinaan kualifikasi, kompetensi dan peningkatan karier pendidik sebagai jabatan fungsional. Kualifikasi dan kompetensi profesional diharapkan berdampak terhadap peningkatan kinerja dan hasil kerjanya. Sedangkan pengembangan karier diharapkan berdampak terhadap kesejahteraannya (Sudjana, 2006).

\section{MUTU PENDIDIKAN}

Upaya peningkatan mutu pendidikan merupakan perioritas dalam pelaksanaan pembangunan pendidikan nasional, terutama dalam penuntasan wajib belajar 9 tahun. Mutu merupakan suatu hal yang membedakan 
antara yang baik dengan yang buruk, atau hal yang membedakan antara kesuksesan dengan kegagalan. Dalam bidang pendidikan mutu merupakan masalah pokok yang akan menjamin perkembangan sekolah/madrasah dalam meraih kesuksesan di tengah-tengah persaingan pendidikan yang keras.

Mutu pendidikan akan dapat dicapai apabila ada kerja sama yang baik dari seluruh unsur yang terkait dalam proses pendidikan, seperti adanya partisipasi aktif mulai dari kepala sekolah, guru, siswa, staf dan orang tua siswa serta dukungaan dari masyarakat sekitar sekolah/madrasah. Di samping itu untuk mewujudkan konsep mutu supaya berhasil dengan baik, maka setiap personil sekolah/ madrasah harus memiliki disiplin yang tinggi untuk mencapai tujuan yang telah dirumuskan.

Untuk menjaga mutu pembelajaran, lembaga pendidikan harus berupaya memberikan pembinaan dan pengembangan profesi guru. Upaya ini dilakukan untuk memberikan dorongan para guru agar tetap mempunyai semangat dan motivasi yang sama dalam mengemban tugasnya sebagai tenaga pendidik.

\section{METODE PENELITIAN}

Penelitian ini dilakukan dengan menggunakan pendekatan kualitatif deskriptif. Penelitian deskriptif adalah penelitian yang bertujuan untuk mendeskripsikan atau mengambarkan fenomena-fenomena yang ada. Penelitian deskriptif tidak memberikan perlakuan, manipulasi atau pengubahan pada variabel-variabel bebas, tetapi mengambarkan suatu kondisi apa adanya.

Dalam penelitian ini, peneliti ingin mengambarkan bagaimana pembinaan pengembangan profesi guru dan dampaknya terhadap mutu pendidikan di MTs TI Tanah Datar, karena itu penelitian deskriptif dianggap sangat tepat digunakan dalam penelitian ini. Penelitian ini termasuk penelitian kualitatif, yaitu penelitian yang dianalisis berdasarkan logika berpikir ilmiah. Penelitian ini dilakukan di MTs TI di Kabupaten Tanah Datar yang meliputi, MTs TI Pariangan, MTs TI Tanjung Barulak, MTs TI Jaho. Waktu penelitian ini dilaksanakan selama bulan Mei sampai Juli 2014. Adapun sumber data dari penelitian ini adalah majelis guru dan kepala madrasah MTs TI Tanah Datar. Teknik pengumpulan data yang digunakan dalam penelitian ini adalah observasi, wawancara dan dokumentasi.

Observasi ialah pengamatan dan pencatatan yang sistematis terhadap gejalagejala yang diteliti (Usman dan Akbar, 1996). Dalam observasi penelitian ini, halhal yang menjadi perhatian penulis adalah bagaimana usaha pembinaan pengembangan profesi guru dan dampaknya terhadap mutu pendidikan di MTs TI Tanah Datar. 
Wawancara adalah suatu cara untuk mendapatkan keterangan secara lisan dari responden/informan dengan bercakapcakap, dengan tujuan untuk mengumpulkan keterangan demi mengumpulkan data yang respresentatif(Hanafi, 2011). Di sini peneliti mengadakan wawancara secara langsung dengan pihak terkait yaitu (Guru dan Kepala MTs TI Kabupaten Tanah Datar) tentang bagaimana pembinaan pengembangan profesi guru di MTs TI Kabupaten Tanah Datar. Dokumentasi adalah data berupa catatan, buku-buku, transkip mengenai halhal yang diselidiki. Dokumentasi peneliti lakukan dengan mengumpukan data tentang Guru di MTs TI Kabupaten Tanah Datar.

\section{HASIL PENELITIAN DAN PEMBAHASAN}

Pembinaan dan pengembangan profesi guru merupakan kewajiban sekolah dalam rangka menempatkan guru sebagai mitra profesi yang bergerak pada pelayanan jasa. Karenanya, pimpinan sekolah dalam hal ini memegang peranan penting untuk melaksanakan secara berkesinambungan. Untuk menjaga mutu pembelajaran, lembaga pendidikan harus berupaya memberikan pembinaan dan pengembangan profesi guru. Upaya ini dilakukan untuk memberikan dorongan para guru agar tetap mempunyai semangat dan motivasi yang sama dalam mengemban tugasnya sebagai tenaga pendidik.
Tanggung jawab pembinaan guru terletak di tangan kepala sekolah. Tujuan pembinaan guru adalah untuk meningkatkan kemampuan professional guru dalam meningkatkan proses dan hasil belajar melalui pemberian bantuan yang terutama bercorak layanan profesional kepada guru. Jika proses belajar mengajar meningkat, maka hasil belajar diharapkan juga meningkat. Dengan demikian rangkaian usaha pembinaan professional guru akan memperlancar pencapaian tujuan kegiatan belajar mengajar.

Berdasarkan wawancara yang dilakukan di MTs TI Pariangan adapun jenis-jenis kegiatan pengembangan profesionalisme guru dilaksanakan melalui berbagai strategi dalam bentuk pendidikan dan pelatihan (diklat) maupun bukan diklat di antaranya adalah pembinaan internal sekolah yang dilakukan oleh kepala sekolah dan guruguru yang memiliki kewenangan membina, melalui rapat dinas, rotasi tugas mengajar, pemberian tugas-tugas interal, dan lainlain. Melalui rapat dinas yang dilakukan sebulan sekali, Kepala Madrasah beserta guru bisa bertukar pikiran mengenai pembaharuan kebijakan pendidikan dan proses pembelajaran yang terjadi, baik itu berasal dari Kepala Sekolah maupun dari guru Nota Tugas dari sekolah lain, sehingga guru-guru tidak pernah ketinggalan informasi yang terbaru. 
Pemberian izin belajar dan tugas belajar pun selalu terjadi di MTs TI Pariangan, menurut Drs Tarmizi (Hasil Wawancara), hal ini dimaksudkan supaya mampu menghasilkan guru-guru pembina yang dapat membantu guru-guru yang lain untuk meningkatkan profesionalisme guru. Mengikutsertakan guru-guru mata pelajaran dalam workshop atau MGMP, BIMTEK yang diadakan oleh pemerintah Kabupaten, maupun gabungan beberapa buah Madrasah di Kabupaten.

Pada MTs TI Tanjung Barulak pembinaan profesi guru dapat diketahui bahwa dalam usaha meningkatkan mutu pendidikan, setiap guru diberikan bimbingan atau pembinaan sebelum menghadapi siswa di dalam kelas. Guru diharapkan mampu mengutamakan kualitas pembelajaran, dan tidak hanya mengutamakan ketuntasan materi saja namun juga seberapa besar materi yang diajarkan tersebut dapat dikuasai oleh peserta didik. Di samping itu, guru juga diharapkan untuk berpedoman pada keberhasilan pembelajaran pada masa yang lalu, dan mengevaluasi jika terdapat kekurangan selama proses pembelajaran pada tahun yang lalu sehingga hasil yang didapatkan nanti menjadi lebih baik untuk kedepannya.

Berdasarkan pembicaraan yang dilakukan dengan Drs. Ahmad Rizal (Kepala MTs TI Jaho) "pembinaan pengembangan profesi guru masih dilakukan secara kontemporer, guru yang lebih senior membina yang junior dengan mengacu kepada buku-buku/kitabkitab klasik yang telah terbukti pernah menghasilkan para ulama sepanjang sejarah". Guru senior dipandang lebih mampu memberikan pengetahuan serta informasi yang akurat. Kegiatan musyawarah dan rapat dinas setiap bulan, walaupun tidak sepenuhnya mampu mengembangkan profesi guru, tapi dipandang cukup membantu guru dalam menjalankan tugas dan tanggung jawab mereka sebagai pendidik. Terlebih untuk guru honor yang pengalaman mengajarnya masih baru, dengan adanya rapat setiap bulan, ia bisa menanyakan setiap hal yang belum dikuasai, walau tidak menutup kemungkinan ia bisa menanyakan persoalannya kapanpun, namun pada saat rapat dinas tentu lebih banyak lagi pendapat guru yang bisa ia dapatkan, dan lebih banyak lagi masukan untuk pengembangan profesi keguruannya.

Dalam penelitan ini peneliti mendapatkan gambaran apa adanya tentang usaha pembinaan pengembangan profesi guru dan dampaknya terhadap mutu pendidikan di tiga satuan pendidikan yaitu MTs TI Pariangan, MTs TI Tanjung Barulak dan MTs TI Jaho. Hasil penelitian ini didukung oleh temuan Pramujaya (2009) yang mengemukakan bahwa untuk meningkatkan mutu Pendidikan 
Agama Islam perlu dibentuk kerja sama pengawas dengan Kepala Sekolah kemudian mencari dan memecahkan kendala-kendala yang dihadapi.

\section{KESIMPULAN}

Usaha pembinaan pengembangan profesi guru di MTs TI Tanah Datar khususnya di MTs TI Pariangan, MTs TI Tanjung Barulak dan MTs TI Jaho masih belum baik, tanggung jawab pembinaan pengembangan profesi guru masih diserahkan kepada Kepala Madrasah masing masing. Masih kurangnya peran serta pemerintah daerah penyelenggara satuan pendidikan dalam hal pembinaan pengembangan profesi guru, hal ini bisa dilihat dari kegiatan workshop, MGMP atau BIMTEK yang masih mengutamakan mata pembelajaran umum saja, untuk mata pelajaran PAI kegiatan seperti workshop masih tidak berjalan dengan baik.

\section{KEPUSTAKAAN ACUAN}

Hanafi, Abdul Halim. (2011). Metode

Penelitian Kependidikan. Batusangkar: STAIN Batusangkar Press.

Kunandar. (2008). Guru Profesinal Implementasi Kurikulum Tingkat Satuan Pendidikan (KTSP) dan Sukses dalam Sertifikasi Guru. Jakarta: PT. Raja Grafindo.
Mujtahid. (2011). Pengembangan Profesi Guru. Malang: UIN Maliki Press.

Pramujaya, Sondal. (2009). Kerjasama Pengawas dan Kepala Madrasah dalam Meningkatkan Mutu Pendidikan Agama Islam di MTsN Kota Padang. Padang: Tesis IAIN Imam Bonjol.

Rivai, Veithzal. (2009). Islamic Human Capital. Jakarta: PT Raja Grafindo Persada.

Sudjana, Nana. (2006). Standar Mutu Pengawas. Jakarta: Depdiknas.

Sutisna, Oteng. (1983). Administrasi Pendidikan, Dasar Teoritis Untuk Praktek Profesional. Bandung: Angkasa.

Tim Redaksi KBBI. (2011). Kamus Besar Bahasa Indonesia. Edisi keempat. Jakarta: PT Gramedia.

Undang-Undang Nomor 14 Tahun 2005

Usman, Husaini dan Akbar, Purnomo Setiadi. (1996). Metodologi Penelitian Sosial. Jakarta: Bumi Aksara. 